Review Article

\title{
Fecal Sludge Management in Developing Countries: Developing Countries Comparison
}

\author{
Nadia Paramita ${ }^{1^{*}}$, Raldi Hendrotoro Seputro Koestoer ${ }^{1,2}$ \\ ${ }^{1}$ School of Environmental Science, Universitas Indonesia, Jakarta, Indonesia \\ ${ }^{2}$ Coordinating Ministry for Economic Affairs, Jakarta, Indonesia \\ *Corresponding Author, e-mail: nadiaparamita411@gmail.com
}

\begin{abstract}
Several factors that influence the achievement of the sustainability of an MSS management system are identified. This study aims to determine what aspects of sustainability affect a system's municipal wastewater sludge management to run appropriately using conventional technology. The method used in this research is a comparative approach. The study compares urban domestic wastewater focusing on fecal sludge management (FSM) in Egypt and Indonesia. It is known that the sustainability factor of wastewater management systems includes economic, social, environmental, and technological factors. In Indonesia, institutional, which is also included in the social aspect, becomes the most significant limitation to implement the appropriate FSM. The best technology chosen for Egypt is anaerobic digestion, while in Indonesia, the right technology chosen is sludge drying bed (SDB) and also the combination of solid separation chamber (SSC) with draining area (DA). From an economic point of view, the 2 sub-factors that influence the sustainability system are investment cost and operation and maintenance cost. Regarding socio-culture, the awareness and participation of the community and the private sector needs to be increased to achieve the sustainability of sludge management services in both countries
\end{abstract}

Keywords: fecal sludge management, Egypt, Indonesia, sustainability factors

\section{Introduction}

The rising quantity of sludge generated by municipal wastewater treatment plants (WWTP) presents a problem for Egypt's drinking water and sanitation sectors, resulting in significant environmental contamination due to the usage of unstable sludge (Wahaab et al., 2020). Egypt produces approximately 2.1 million tons of excess fecal sludge every year, which is not appropriately treated, making it potentially pollute the environment. In Egypt, municipal wastewater treatment plants (WWTP) availability is still considered less than optimal in processing existing municipal sewage sludge (MSS). From the data found, Egypt has 27 regional divisions (governorates) with total availability of 415 WWTPs that treat 4,4 billion $\mathrm{m}^{3}$ /year (Zeid and Elrawady, 2014).

Similar to what is faced in Egypt, the lack of availability of WWTPs and fecal sludge treatment plants (FSTP) in Indonesia creates environmental problems. Managing fecal sludge is also still an environmental problem because it has not been appropriately handled. The facilities and infrastructure for distribution and processing have not been sufficient. Only 10\% of FSTP work in proper operation. The Indonesian Environmental Statistics Report 2020 shows that more than half of households, or 
$57.42 \%$ in Indonesia, dispose of bathing, washing, and kitchen wastewater directly into sewers. Approximately 2.1 million tons of extra sludge are generated annually, averaging $0.48 \mathrm{~kg}$ of sludge per 1 $\mathrm{m}$ of treated wastewater. Indonesia, a country with 34 provinces, only has 134 FSTP and 5 FSTP that are useful and work optimally (Putri, 2015). According to data from the Ministry of Public Works and Public Housing (2019), Indonesia only has 15 municipal WWTPs from a total of 34 provinces or $44 \%$ of the total existing.

Sludge from urban wastewater treatment processes is an unavoidable by-product of biological wastewater treatment processes, which typically require high costs for proper handling, disposal, and treatment, frequently accounting for $30-40 \%$ of capital costs and approximately $50 \%$ of operating expenses for all WWTPs (Andreoli et al., 2007). Sludge contains a diverse range of pollutants, including organic substances, nutrients, and pathogens, all of which contribute to smells and hygiene issues. Because sludge is one of the most severe environmental challenges, it requires suitable treatment and management solutions (Jimenez et al., 2004). Sludge amount and quality are highly impacted by several parameters, including the wastewater treatment technology employed, treatment efficiency, and the volume and content of incoming wastewater.

Conditions for sludge management and disposal are harsher in underdeveloped nations. Due to budgetary restrictions and lax enforcement of environmental legislation, developing countries cannot properly dispose of municipal wastewater sludge, resulting in significant environmental contamination (Jimenez et al., 2004). The lack of public knowledge about the importance of managing domestic wastewater and the minimum fecal sludge makes an urban management system unable to work correctly, causing environmental pollution (Paramita, 2009). On the other hand, Egypt and Indonesia continue to prioritize municipal wastewater treatment above sludge disposal and management. Consequently, in Egypt and Indonesia, disposing of municipal wastewater sludge remains a challenging undertaking. In fact, according to Zhen et al. (2017) and Apples et al. (2008), reducing the amount of sludge at the time of disposal can provide benefits in the form of sludge stability, destroyed pathogens, and control of odor emissions produced.

This research was conducted because the two countries have similar conditions related to the management of feces that have not been optimum and have the same strategy in overcoming these problems through analysis of sustainability factors, namely technological, socio-cultural and financial aspects. Thus, the purpose of this study is to understand from the part of having a continuation what affects a municipal wastewater sludge management system so that the system can run properly using the appropriate technology.

\section{Methods}

This study used literature review and critical analysis to compare the strategy for achieving sustainable fecal sludge management in Egypt and Indonesia. This study emphasizes 4 aspects of wastewater management: technology, environmental, social, and economics on the sustainability of municipal wastewater management, focusing on fecal sludge management. The literature review is taken from scientific publications, project reports, and findings published in journals between 2009 and 2020 of fecal sludge management. The results of this literature review will be used to analyze the appropriate strategy for Indonesia for the sustainable management of a regular desludging program on fecal sludge management.

\section{Results and Discussion}

\subsection{Technological Aspects}

Anaerobic digestion is one of the technologies used to manage sewage sludge. Anaerobic microorganisms stabilize organic matter and produce biogas is a biological treatment process. The process of digestion occurs when organic matter decomposes in an oxygen-free environment. Some digester systems are divided into "wet" and "dry" digesters, or low solid and high solid systems, and 
sometimes the process is called fermentation (Shahab, 2020). Bioenergy generation, biomass reduction, and sludge volume are widely practiced by anaerobic digestion (Yuan and Zhu 2016).

Design standardization that can be used in planning FSTP in Indonesia for the Imhoff Tank section, the opinion of the SSC section with DA perspective, anaerobic pond, facultative pond, maturation pond, oxidation ditch, and anaerobic digester and sludge drying bed (Azizah, 2017). In addition, according to Apples et al. (2011) and Natsir et al. (2012), anaerobic digestion is a technology for treating organic waste and sludge, which is environmentally friendly and economical.

The scenario recommended in the technological aspect in Egypt is sludge stabilization which can be achieved through one of the technical stabilization approaches, such as (1) anaerobic digestion, (2) anaerobic co-digestion, (3) windrow composting, and (4) storage lagoon. Based on the sustainability criteria and orientation to renewable energy and the availability of fertilizers for agricultural purposes, the technology using anaerobic digestion is considered the highest priority option (Zeid and Elrawady, 2014).

Meanwhile, in Indonesia, the consideration for treating fecal sludge is technology, cost, operation, and maintenance. Sludge thickeners and dryers, which are generally suitable for use in Indonesian wastewater treatment plants, are to use sludge drying bed (SDB) and a combination of solid separation chamber (SSC) with draining area (DA). According to the number of people served, suitable stable treatment units for WWTPs in Indonesia are stabilized ponds in medium-sized cities, oxidation ditches in metropolitan areas, and small urban areas with an anaerobic digester. It is not enough in the sustainability of a system, technology determination, and technical. The solutions from social and moral aspects must be a package (Keraf, 2010).

Institutions and administration, rather than technology, are the primary impediments to urban fecal sludge disposal in Egypt. Additionally, the absence of a legislative and legal framework inhibits the widespread use of appropriate disposal procedures, particularly in rural regions (Said et al., 2013). The high expenses associated with sludge management and disposal account for up to $50 \%$ of total wastewater treatment plant operating and maintenance costs. In Egypt, the government subsidizes and financially supports wastewater treatment. In Egypt, wastewater treatment is costly due to low wastewater and poor resource recovery rates.

\subsection{Environmental Aspects}

In general, wastewater management institutions have been formed, but regulators and operators are still not separated. In addition, the funds prepared by the regions to support the management of fecal sludge are still small. They still do not support regulations regulating wastewater management resulting in less-than-optimal FSTP operations (Budi, 2014). The success of some FSTPs in Indonesia is supported by the preparation of a transparent system and system, so that maintenance and operation can be carried out smoothly (Putri, 2015). According to Azizah (2017), district/city sludge management agencies can have several choices, such as:

a. Fecal Sludge Management Agency as a regional apparatus,

b. Fecal Sludge Management Agency as regional public service agency financial management pattern (PPK-BLUD),

c. Fecal Sludge Management Agency as a regional owned enterprise (Badan Usaha Milik Daerah BUMD).

Over the past few decades, Egypt has focused on providing drinking water and sanitation-related services, particularly building new sludge networks and wastewater treatment facilities, with a lack of attention to managing excess sludge generated from wastewater treatment. This situation is reflected in local regulatory and statutory standards, often imported from more developed industrialized countries without adapting to local conditions (Zeid and Elrawady, 2014). In determining sustainability in Egypt, institutions have not been considered aspects in assessing the sustainability of the MSS management system. In Indonesia, several forms of institutions have the task of managing urban 
wastewater, namely in the form of Regional Apparatus, PPK-BLUD, and BUMD (Azizah, 2017). The existence of an institution that functions to carry out environmental management in the management of fecal sludge/MSS is vital so that the implementation of waste management can be more secure and well structured.

In Indonesia, the institutional aspect significantly influences whether a wastewater management system will continue or not. It shows that regulations and sanctions still affect people's behavior to run a system. Not many regions have rules regarding sanctions against the community regarding the disposal of domestic fecal sludge into the environment. Only a few areas, one of which is Probolinggo, already have regulations containing sanctions for the community. In Local Regulation (Perda) Number 1 the Year 2019, it is even stated that there is a criminal penalty of 3 years or a fine of Rp. 50,000,00o for individuals who dispose of their domestic waste carelessly.

\subsection{Social Aspects}

The social aspect, which is community participation, is an important aspect. The quality of the environment depends on the involvement of the community. Lack of public awareness in managing the wastewater causes less optimal performance of other elements. The lack of community participation is related to their attention to environmental management due to a lack of understanding and knowledge of the environment. People in developing and emerging countries still have low Eco literacy. People do not yet know the importance of the environment, the importance of maintaining and caring for the earth, ecosystems, and nature as a place to live and develop their lives (Keraf, 2014). According to Zhou (2020), The local community is the main stakeholder category in the waste treatment system. According to Paramita (2009), the priority aspect in determining the sustainability strategy of domestic wastewater infrastructure is the socio-cultural aspect, while the main sub-criteria is the comfort/acceptance of the community. The second priority is financial, and the last is the technical aspect.

\subsection{Economic Aspects}

The situation of sludge management and disposal in developing countries is currently deteriorating. Due to financial constraints and limited enforcement of environmental laws, developing countries often do not have adequate capacity to deal with fecal sludge in urban wastewater, resulting in severe environmental pollution (Jimenez et al., 2004 and Shaddel, 2019). From a financial perspective, the costs of various waste sludge management strategies are very high. It is estimated that about $50 \%$ of the operating expenses of secondary sewage treatment plants in Europe can be attributed to the treatment and disposal of fecal sludge (Kacprzak et al., 2017). The two countries show that the economic aspect is exceptionally influential on the sustainability of the sewage management system. It is shown that the availability of investment costs and operational costs of maintenance are two sub-factors that must be present and considered to achieve the sustainability of the sewage management system.

\subsection{Sustainability of Fecal Sludge Management in Comparison}

Egypt's wastewater treatment method is mainly based on activated sludge. Around 2.1 million tonnes of dry solids are generated yearly. Except for those in districts with a high level of life, most WWTPs in Egypt lack adequate sludge stabilization facilities (Cairo, Alexandria, and Giza). As a result, about 85 percent of unstabilized sludge is inappropriately disposed of and is directly employed in agriculture. Converting sludge to value-added goods, such as renewable energy, may significantly cut wastewater treatment costs and fossil energy use, lowering WWTP greenhouse gas emissions.

Nonetheless, sludge management is a significant environmental, regulatory, and financial burden for the sanitation industry, particularly WWTP operators. For instance, due to the strict legality of fecal sludge in most developed nations, it needs considerable treatment before being utilized as a beneficial fertilizer for land restoration. Various chemical, physical, and biological processes thicken and dewater sludge and dry and stabilize it (Turovskiy and Mathai, 2006). Management practices for urban 
fecal sludge are not alike between one country to another. Egypt and Indonesia are different in terms of quantity and quality of fecal sludge; thus, it is necessary to be directed according to the conditions of each country. In both countries, selecting an appropriate sludge disposal system remains a difficulty. Egypt and Indonesia face institutional, social, economic, and technological impediments. From the literature analysis by comparing the two country conditions, it is known that the sustainability of a waste management system in an area is influenced by economic, social, environmental, and technological factors. For Indonesia, the sustainability factor is added by the influence of institutions. The technology chosen for Egypt is Anaerobic Digestion.

In contrast, for Indonesia, The technology chosen is a sludge drying bed (SDB) and also a combination of solid separation chamber (SSC) with draining area (DA). Regarding socio-culture, the awareness and participation of the community and the private sector needs to be increased to achieve the sustainability of sludge management services in both countries. From an economic point of view, to ensure that a fecal sludge management system can run sustainably, it is necessary to ensure the availability of investment costs and operational and maintenance costs (See Table 1).

Table 1. Sustainability assessment of fecal sludge management

\begin{tabular}{|c|c|c|c|c|c|c|}
\hline Aspect & Sub Aspect & $\begin{array}{l}\text { Anaerobic } \\
\text { digestion }\end{array}$ & $\begin{array}{l}\text { Aerobic } \\
\text { composting }\end{array}$ & $\begin{array}{l}\text { Anaerobic } \\
\text { Co-digestion }\end{array}$ & $\begin{array}{l}\text { Agriculture } \\
\text { reuse }\end{array}$ & Landfill \\
\hline \multirow{3}{*}{$\begin{array}{l}\text { Economic } \\
\text { Aspect }\end{array}$} & \multirow{3}{*}{$\begin{array}{l}\text { investment costs } \\
\text { operational \& } \\
\text { maintenance } \\
\text { costs } \\
\text { profits }\end{array}$} & $\mathrm{O}$ & $\mathrm{O}$ & $\mathrm{o}$ & 1 & $\mathrm{o}$ \\
\hline & & 1 & o & o & o & o \\
\hline & & 1 & o & 1 & 1 & -1 \\
\hline \multirow{4}{*}{$\begin{array}{l}\text { Socio-cultural } \\
\text { aspects }\end{array}$} & \multirow{4}{*}{$\begin{array}{l}\text { social acceptance } \\
\text { heavy metal- } \\
\text { associated risk } \\
\text { pathogen- } \\
\text { associated risk } \\
\text { emissions }\end{array}$} & 1 & o & 1 & o & o \\
\hline & & o & o & o & o & o \\
\hline & & o & o & o & o & 1 \\
\hline & & o & $\mathrm{O}$ & o & o & o \\
\hline \multirow[t]{9}{*}{$\begin{array}{l}\text { Environmental } \\
\text { aspects }\end{array}$} & $\begin{array}{l}\text { recovered value- } \\
\text { added products }\end{array}$ & 1 & o & 1 & 1 & o \\
\hline & $\begin{array}{l}\text { solid residues to } \\
\text { be disposed }\end{array}$ & 1 & o & 1 & o & -1 \\
\hline & \multirow{3}{*}{$\begin{array}{l}\text { land requirement } \\
\text { transportation } \\
\text { odors }\end{array}$} & o & -1 & o & o & 1 \\
\hline & & 1 & -1 & -1 & o & o \\
\hline & & o & -1 & o & o & -1 \\
\hline & noise & o & o & o & o & $\mathrm{O}$ \\
\hline & $\begin{array}{l}\text { heavy metal } \\
\text { emission risk }\end{array}$ & o & o & o & o & o \\
\hline & $\begin{array}{l}\text { pathogen } \\
\text { emission risk }\end{array}$ & o & o & o & o & o \\
\hline & air emission risk & o & o & o & 1 & -1 \\
\hline \multirow{6}{*}{$\begin{array}{l}\text { Technological } \\
\text { aspects }\end{array}$} & reliability & 1 & o & 1 & 1 & o \\
\hline & $\begin{array}{l}\text { flexibility and } \\
\text { modularity }\end{array}$ & 1 & o & 1 & 1 & o \\
\hline & complexity & o & $\mathrm{o}$ & o & o & o \\
\hline & $\begin{array}{l}\text { personal } \\
\text { requirements }\end{array}$ & o & o & o & o & 1 \\
\hline & $\begin{array}{l}\text { reagent's } \\
\text { consumption }\end{array}$ & o & o & o & o & o \\
\hline & $\begin{array}{l}\text { energy } \\
\text { consumption }\end{array}$ & o & o & o & 1 & 1 \\
\hline \multicolumn{2}{|c|}{ Overall ranking } & 1 & o & o & o & o \\
\hline
\end{tabular}


The implementation of regular fecal sludge desludging is one of the solutions for domestic wastewater management in Indonesia. It has seven aspects of sustainability. According to Indonesia Urban Water, Sanitation, and Hygiene (2018), the seven aspects are a pattern of operations, customers, infrastructure, institutions, procedures, finances, and regulations. These prospects are a unified system that supports each other to ensure excellent and sustainable operations. As Endang (2015) mentioned, sustainability factors of municipal wastewater facilities and infrastructure consist of five main variables: institutions, environment, technology, financial-economic and socio-cultural.

The component of the institutional sustainability variable consists of two sub-variables, namely wastewater system regulations \& penalties, and environmental protection regulations \& penalties. For environmental sustainability, three sub-variables are affected: safety in water sources, raw material efficiency, and wastewater minimization. A system must have several criteria regarding technology selection, including system resilience, spare parts convenience, operational ease, and adaptability. from a financial and economic perspective, the sustainability of wastewater infrastructure must have sustainability in terms of investment costs, operating costs, and the ease of local development. in sociocultural variables, system sustainability will be achieved if the community has a willingness to pay, acceptance or community acceptance, local capacity, and local cultural conformity. The highest sustainability effect was obtained from the institutional aspect of $20.3 \%$, followed by environmental factors $19.7 \%$, technology factors $15.6 \%$, financial economy at $14.6 \%$, and the lowest influence was sociocultural influences, which was $12,8 \%$.

There is a slight difference with the sustainability factor found in Egypt. There are only four sustainability factors in the analysis conducted by Wahaab RW (2021). Meanwhile, in Endang's research (2015), five variables determine sustainability. One aspect that distinguishes it is the institutional variable. The existence of regulations with supervision and law enforcement in the environmental field is an essential factor in environmental protection and management that will significantly determine the success of environmental protection and control (Keraf 2010). Both Egypt and Indonesia already have regulations covering urban wastewater management activities, especially those related to fecal sludge management. Unfortunately, in implementing this regulation, it has not been supported by equal law enforcement; this is due to the lack of regulations related to sanctions or penalties for communities and institutions that violate them by not properly managing their fecal sludge. Based on Guidelines for Drafting Regional Head Regulations on Sludge Management (Marsaulina et al., 2018), the imposition of sanctions related to fecal sludge is regulated in each regional regulation, causing uniformity in sanctions highly dependent on the amount of political will of each regional leader.

\section{Conclusions}

From this article, it is recommended that in the legal aspect, basic regulations are needed as the basis for enforcing sanctions so that they can be implemented in all regions. In the financial part, involving the private sector and the community both in funding and related to the results will support sustainability. In addition, improvements are needed in the payment mechanism to make it easier for the community through applications. Technological aspects can be improved by increasing the efficiency of existing technologies and selecting reuse-based technologies. Reliable power is needed to support the sustainability of the system. For this reason, collaboration with the world of education and research is required to prepare dedicated personnel in wastewater and sewage treatment. On the environmental aspect, to achieve equitable distribution of domestic wastewater services, it is necessary to increase the coverage of services to rural areas and increase public awareness to manage domestic waste properly.

\section{References}

Abu Zeid, K., Elrawady, M. 2014. The strategic vision of treated wastewater reuse in Egypt. Cairo, Egypt: Center for Environment \& Development for the Arab Region \& Europe (CEDARE) 
Andreoli, CV., Speling, MV., Fernandes, F. 2007. Sludge Treatment and disposal. London: Iwa Publishing.

Appels, L., Baeyens, J., Degr'eve, J., Dewil, R. 2008. Principles and potential of the anaerobic digestion of waste activated sludge. Progress in Energy and Combustion Science (34), 755-81.

Appels, L., Joost, L., Degrève, J., Helsen, L., Lievens, B., Willems, K., Jan, VI., Raf, D. (2011). Anaerobic digestion in global bio-energy production: potential and research challenges Renewable and Sustainable Energy Reviews (15), 4295-4301.

Azizah, CA. 2017. Scheduled sludge service in Lowokwaru District, Malang City. Thesis, Institut Teknologi Sepuluh November.

Endang, SRN. 2014. Identification of sustainability factors for the provision of household wastewater facilities and infrastructure using the sem and ahp methods (a case study in the sub-districts of Setiabudi and Tebet, South Jakarta). Dissertation, Institut Teknologi Bandung.

International Urban Water and Sanitation Hygiene. 2018. Scheduled sludge service training (L2T2) syllabus and module - 4 Getting to know L2T2. USAID - Indonesia Urban Water Sanitation and Environmental Hygiene for All (IUWASH PLUS).

JimEnez, B., Barrios, JA., Mendez-Contreras, JM., Diaz, J. 2004. Sustainable sludge management in developing countries. Water Science Technology, 251-258.

Paramita, N. 2009. Selection of community-based sustainable local sanitation processing through the PNPM Mandiri Program (Case Study: Sadang Seran Village Bandung). Thesis, Institut Teknologi Bandung.

Kelessidis A, Stasinakis AS. 2012. Comparative study of the methods used for treatment and final disposal of fecal sludge in European countries. Waste Management, 32-95.

Ministry of Public Works and Public Housing. 2019. Wastewater Treatment Agency (WWTP)

Keraf, S. 2014. Environmental Philosophy. Jakarta: PT. Canisius.

Keraf, S. 2010. Environmental Ethics. Jakarta: PT. Kompas Media Nusantara.

Metcalf, E. 2003. Wastewater engineering-treatment and reuse, revised by Tchobanoglous, G., Burton, FL, Stensel, HD fourth ed. New York: McGraw-Hillinc.

Nasir, I. M., Tinia, I M G., Rozita, O. 2012. Production of biogas from solid organic wastes through anaerobic digestion: a review. Applied Microbiology and Biotechnology (95), 321-329.

Putri, NC. 2015. A Study on implementation of sludge treatment plants in Indonesia. Thesis, Institut Teknologi Sepuluh November.

Wahaab, RW., Mohamed, M B., Jules, B., van, L C. 2020. Toward achieving sustainable management of municipal wastewater sludge in Egypt: The Current Status and Future.

Shahab, AA. 2020. Planning for sludge treatment installation (FSTP) in Citra Wisata Housing using Anaerobic Digestion. Thesis, Universitas Sumatra Utara.

Said, N., El-Shatoury, SA., Díaz, LF., Zamoran, M. 2013. Quantitative appraisal of biomass resources and their energy potential in Egypt. Renewable Sustainable Energy Reviews, 84-91.

Turovsky, I S., Mathai, P K. 20o6. Wastewater sludge processing. Hoboken, New Jersey: John Wiley \& Sons, Inc.

Yuan, H P., Zhu, N W., 2016. Progress in inhibition mechanisms and process control of intermediates and by-products in sewage sludge anaerobic digestion. Renewable and Sustainable Energy Reviews (58), 429-438.

Zhen, G., Lu, X., Kato, H., Zhao, Y., Li, YY. 2017. Overview of pretreatment strategies for enhancing sewage sludge disintegration and subsequent anaerobic digestion: current advances, full-scale application and future perspectives. Renewable and Sustainable Energy Reviews (69), 559577.

Zhou, G., Gua, Y., Yuan, H., Gonga, Y., Wu, Y. 2020. Selecting sustainable technologies for disposal of municipal sewage sludge using a multi-criterion decision-making method: A case study from China. Elsevier. Resources, Conservation \& Recycling (161), 104881. 